\title{
Women's Scientific Participation in Political Science and International Relations in Brazil
}

\author{
Marcos Vinícius Isaias Mendes' 0000-0001-7512-8533 \\ Ariane Cristine Roder Figueira ${ }^{2}$ 0000-0002-2900-3040 \\ 'Universidade de Brasília, Instituto de Relações Internacionais, Brasília, DF, Brasil. \\ 70904-970 \\ 2Universidade Federal do Rio de Janeiro, Instituto Coppead de Administração, Rio de \\ Janeiro, Rio de Janeiro, RJ, Brasil. 21941-918
}

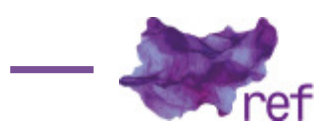

\begin{abstract}
This article maps the participation of women in Brazilian scientific production in the areas of Political Science and International Relations, from 2006 to 2016. To do so, six indicators were created, to measure women's participation in the production of master's dissertations, doctoral theses and scientific papers, as well as their participation as faculty members of graduate programs and their presence on editorial boards of important Brazilian Journals in these fields. The results revealed that, despite an increasing participation of women in recent years, the space they occupy is still underrepresented, especially when considering strategic positions related to education and research.

Keywords: Women; Participation; Gender; Political Science; International Relations.
\end{abstract}

Participação científica da mulher em Ciência Política e Relações Internacionais no Brasil Resumo: Este artigo mapeia a participação das mulheres na produção científica brasileira nas áreas de Ciência Política e Relações Internacionais, no período de 2006 a 2016. Para isso, foram criados seis indicadores, a fim de medir a participação das mulheres na produção de dissertações de mestrado, teses de doutorado e artigos científicos, bem como sua participação como docentes de programas de pós-graduação e sua presença em conselhos editoriais de importantes revistas científicas brasileiras nesses campos. Os resultados revelaram que, apesar de haver uma crescente participação das mulheres nos últimos anos, o espaço que ocupam ainda está sub-representado, especialmente quando se considera posições estratégicas relacionadas ao ensino e pesquisa.

Palavras-chave: mulheres; participação; gênero; ciência política; relações internacionais.

\section{Introduction}

In 1965, the American sociologist Alice Rossi published an article in the journal Science whose title offered the intriguing question: Women in Science: Why So Few? (ROSSI, 1965). In this paper, she argued that, although American society had already become aware of the social disadvantages caused by race and by social class, it remained unmoved in relation to the disadvantages caused by gender. About 30 years later, the same journal published a special issue devoted to women, and in his editorial, Daniel Koshland Jr. noted that the role of women in Science was being debated both inside academia and out. He pointed out, however, that a major change was still needed to break down the historical barriers imposed on women in science and in other areas traditionally dominated by men (KOSHLAND JR., 1993).

The concern demonstrated by Science remains current. Despite advances in some areas such as the increasing participation of women in scientific careers (Everton BATISTA; Sabine RIGHETTI, 2017) and in the labor market (Eugênia LEONE; Marilane TEIXEIRA, 2010), women still suffer disadvantages in several areas. Gender disparities are still present on many fronts and for several 
reasons. For example: the underrepresentation of women in intensive careers in mathematics and other exact sciences (Stephen CECl et al., 2009), the lack of educational opportunities and of encouragement on the part of parents and husbands (KOSHLAND JR., 1993), maternity and family responsibilities (Meg URRY, 2005), subconscious discrimination, and productivity measurements (particularly in academia) that privilege men (Megan HENLEY, 2015), to name a few.

In this context and considering the enormous disparities still present, the field of "gender studies" has achieved great prominence in academia. These studies had their origin in feminist waves that emerged in the late 19th century and built consistency in the 20th century (Seema NARAIN, 2014). Initially with the aim of gaining the woman's right to vote, these currents evolved to the debate of issues on a larger scale, such as the end of discrimination, gender equality policies, and more recently to issues much more extensive and profound, such as the influence of ethnicity, nationality, social class, and religion as sources of differences among women, and discussions on "gender identity".

With the evolution of these studies, today it is possible to speak of several types of "feminisms", which are put into groups ranging from theoretical currents that emerge from more radical socialism to works based on liberal progressivism, with studies employing the most various methodologies ranging from psychoanalytic (Marie HANSEN, 2016) to positivistic (Dan REITER, 2015). A wide range of journals focused on gender studies can also be observed. Some outstanding ones are Gender and Society and Journal of Sex Research, based in the United States, and Psychology of Women Quarterly and Feminist Theory, based in the United Kingdom, all with a high impact factor. Amid this broad spectrum, it is possible to identify an area of studies that Maria Lopes (1998) recognizes as "feminism and science" or "feminist studies of science".

One of the most influential studies in terms of attention to women in science was A Cyborg Manifesto: Science, Technology, and Socialist-feminism in the late Twentieth Century (Donna HARAWAY, 1991). In it, Donna Haraway argues for the need of "a world without gender", making a comparison between humans and cyborgs, which means without the use of categories such as gender to reproduce exclusivist standards that compartmentalize identities and capacities in historically built hierarchies of power. In other words, she defends the idea of a science without gender. More recent papers also tackled the question, such as Henley (2015) who studied the main barriers that prevent women from advancing in scientific careers in the United States, and Urry (2015) who analyzed particularly the low adherence of women in natural and technology sciences such as Physics, Astronomy, and Engineering.

In Brazil, these studies had their origins in authors such as Fanny Tabak (Bruna VASCONCELLOS; Márcia LIMA, 2016), a pioneer in studies on women's participation in politics and in higher education in the country, and were continued in studies such as Lopes (1998) who argued in favor of a systematic building and the strengthening of the area of studies on women/gender in sciences. Other important works in this context were those of Léa Velho and Elena León (1998) who evaluated quantitatively the participation of women on the faculty of four institutes of Unicamp (State University of Campinas), and Jacqueline Leta (2003) who analyzed the participation of women as students and faculty of UFRJ (Federal University of Rio de Janeiro) and USP (University of São Paulo), as well as the participation of researchers as leaders in research groups registered with CNPq (National Council for Scientific and Technological Development). These studies concluded that women were (and still are) underrepresented in various contexts in the Brazilian scientific scenario.

Specifying a little more, considering gender studies only in Political Science (PS) and in International Relations (IR), literature shows a great advance in recent decades. The contributions are diverse, ranging from the insertion of feminism in the debate on international security (Laura SJOBERG, 2010; NARAIN, 2014) to the contribution of gender in teaching and research methods in International Relations (Deborah STIENSTRA, 2000; Julie MERTUS, 2007; REITER, 2015). However, studies of this nature are still incipient in Brazil. Although there are some contributions such as Marina Mendes (2011), whose thesis analyzed the participation of women in politics and diplomacy in Brazil, and Izadora Monte (2013) who proposed to discuss gender as a category of analysis for International Relations, no Brazilian empirical or theoretical studies of great expression were found on this theme.

In this context, this paper seeks to help fill this gap in the literature, bringing a mapping of the areas of Political Science and International Relations ${ }^{1}$ in Brazil. The central objective is to analyze the participation of women in scientific production in these areas through some indicators, which are as follows: participation in the authorship of master's dissertations and doctoral theses, presence on the faculty and in positions of coordination of graduate programs, authorship of articles published in highly relevant journals, authorship of articles cited the most in these journals, and female presence on the editorial board of the journals investigated. The period considered for the analysis is from 2006 to 2016 , the graduate programs considered are the 37 categorized by CAPES (Coordination

\footnotetext{
${ }^{1}$ In Brazil the areas of Political Science and International Relations remain incorporated within the evaluation system of
} CAPES, the Brazilian government organ responsible for the country's graduate school guidelines. 
for the Improvement of Higher Education Personnel) in the areas of PS and IR, and the 15 Brazilian journals considered are those ranked in 2015 by CAPES as A1 or A2, which are the ones of higher quality. Thus, the paper aims to contribute to the production of a diagnosis in these areas of knowledge in Brazil with an emphasis on the representativeness of women. However, we do not focus on the social, political, and/or economic causes that have produced this picture. Our intent is to encourage future studies that replicate the investigation of these indicators in other nationalities or other areas of knowledge, resulting in a more complete picture of the integration of women in scientific activity.

This paper is divided into six sections in addition to this introduction. The next three sections deal briefly and respectively with the trajectory of the participation of women in science, gender studies in PS and in IR, and the Brazilian context in relation to these issues. The next section deals with the methodology used in this research, and is followed by the section of results. In the final considerations some implications of this study are presented and suggestions are given for further studies.

\section{Women in Science: brief history, major setbacks, and insertion policies}

Rossi (1965) examined in depth the situation of female participation in careers in the natural sciences, engineering, and medicine in the United States in the 1960s. Upon observing the very low number of women in these professions, the author embarked on a pursuit for the causes of this phenomenon. She identified the following reasons in her findings: priority given to marriage and the family; the "effect" of an interruption in their career associated with a significant withdrawal of women from the labor market between the ages of 24 and 44 (normally the most productive years of a career) to exercise the role of mothers and wives; and the maternal role, which meant that many women abandoned their careers when their children were young.

According to the same author, part of the reasons for this lies in the educational differences between boys and girls. According to her, the four main skills for a scientist (high intellectual abilityespecially spatial and mathematical-, persistence at work, extreme independence, and separation from other people) were developed more in boys (influenced to be competitive, assertive, independent, and dominant in interaction with other children) than in girls (encouraged to have more passive attitudes, be shy and dependent). Because of this, Rossi (1965) believed that a greater insertion of women in scientific careers depended on an education that would stimulate them, including the instruction given by parents and a change in the social mentality, which normally attributed distinct roles for boys and girls.

For Haraway (1991), the problem of underrepresentation of women in science is the product of a broader historical process, one of asymmetrical distribution of power, bringing to an inferior level not only women, but also certain nationalities, ethnic groups, and social classes. Therefore, for this author, there is a "logic of dominance" to which scientific production is one of the tools of control, accessible only to the superior hierarchies. The author defends that the "pen" (understood here as a metaphor for scientific production) is one of the ways to combat this process. In other words, producing science per se would be a form of struggle through which women would express their positions, interests, needs and criticisms in search of a "world without gender", or a reality in which gender does not carry with it shades of power disproportionately distributed.

A recent study by the American Association of University Women (Catherine HILL et al. , 2010) showed that social and environmental factors contribute significantly to the underrepresentation of women in science, in line with what was reported by Rossi (1965). Factors such as the stereotype that boys are better than girls in mathematics have a high influence on performance on tests such as the SAT (Scholastic Assessment Test) and in the future options of a career, discouraging women to choose to study engineering or other scientific fields.

Other obstacles faced by women in scientific careers or that prevent them from opting for such careers were systematically analyzed in the literature, which were as follows: unconscious biases associated with the "male" and "female" roles (ROSSI, 1965; HILL et al., 2010), the family versus career trade-off (CECl et al., 2009), asymmetrical power relations (HARAWAY, 1991), criteria for success and academic productivity that favor men, limited opportunities for academic advising, lack of institutional support for mothers (HENLEY, 2015; URRY, 2015), and discrimination (KOSHLAND JR., 1993).

In parallel, a set of policies has been proposed to facilitate the insertion of women in science. For example: institutional policies that reduce the weight for women, such as a part-time job when having young children (KOSHLAND JR., 1993), measures of productivity that consider academic activities such as teaching and advising graduate students as much as the production of articles, since research indicates that women devote themselves more to those activities (URRY, 2015), family support and encouragement, education that encourages the development of skills related to science, such as curiosity, spatial and mathematical skills, and independence (ROSSI, 1965; URRY, 2015; HILL et al., 2010). 


\section{Gender Studies in Political Science and International Relations}

The inclusion of gender as a methodological and pedagogical source in PS and IR has been discussed for some decades now. Particularly in IR, some authors have engaged in debate on possible ways to teach "gender" in this discipline. Stienstra (2000) explored four approaches to do so: 1) see no evil, read no evil, teach no evil, in which gender is irrelevant; 2) add women and stir: incorporate women, not gender, to the IR debate, exploring just a few "select" issues related to feminist theory, when appropriate; 3) multiple paradigms, which recognizes the multiplicity of possible approaches in IR considering the inter-relationship among them and, therefore, recognizing different forms of feminism and varied approaches to gender in the discipline; 4) gendered IR, in which concepts such as politics, power, autonomy, and cooperation are redefined to reflect gender relations, which are intrinsic to criteria such as race, religion, social class, and geographic location; this involves enormous analytical complexity, requiring that the IR methods and resources be rethought.

Along a similar line, Mertus (2007) identified three variants of feminism in IR. A first approach, which she refers to as equality feminism, seeks to identify situations in which women are "invisible" in IR except when they hold typically male roles. Similar to the add women and stir approach from Stientra (2000), this emphasis argues that the inclusion of more women in all areas of representation would be enough to satisfy the demands of feminism. The second approach, on the other hand, recognizes the existence of asymmetries in gender at the very base of the international political system insomuch that the definition of the problems and relevant groups for IR reflects "male" interests in detriment to the "female" ones. Finally, the third approach recognizes epistemological problems at the root of the knowledge generated in IR, which adopts a typically top-down perspective focused on the State, sovereignty, and power and neglects bottom-up analyses from individuals, social movements and groups, and human relations, therefore generally ignoring or obscuring feminine subordination.

In addition to these different categories of feminism and to the many approaches to gender, IR scholars have used gender to discuss classic questions in International Politics. One case highlighted are the contributions made in the area of International Security, as can be seen in papers from J. Ann Tickner (1992, 2001), Sjoberg (2010), and Narain (2014). Particularly in her book Gender in International Relations: Feminist Perspectives on Achieving Global Security (TICKNER, 1992), professor Tickner challenges the vision of realistic authors such as Hans Morgenthau and Kenneth Waltz about the militarization of the State as a strategy for global security, as well as the neo-realist attempts of applying positivism to IR, using models such as rational choice and the game theory with the justification of inserting "scientific rigor" in the discipline. In contrast to these approaches, Tickner (1992) believes that this objectivity carries "masculine assumptions" with it, disregarding the subjectivity inherent in the production of IR knowledge. According to her, "Feminist reformulations of the definition of security are needed to draw attention to the extent to which gender hierarchies themselves are a source of domination and thus an obstacle to a truly comprehensive definition of security" (TICKNER, 1992 apud NARAIN, 2014, p. 190).

Another interesting and original contribution comes from Jeff Colgan (2017), who investigates the level at which gender biases exist in teaching IR in graduate school. In his study, the author observed significant influences of gender from the teachers in the way that the disciplines from this area are taught, summarizing two findings: 1) women teachers recommend papers by women authors to a greater extent than men teachers do; 2) women teachers are more reluctant to list their own writings as compulsory readings than men teachers. Reiter (2015), in turn, examined emerging literature since the year 2000, which inserts positivism in gender studies and IR. According to him, although the non positivist literature of gender is at the origin of this debate in IR, the positivist literature came to complement it, especially considering the rigor of these studies and since they consider issues that traditionally positivism ignored.

With regard to Political Science in general, the debate on gender has been entering this area especially in recent decades. Drude Daherup (2010) pointed out that PS ignored this debate until the 1970s, but that currently studies of this nature are presented in almost all conferences of the European Consortium for Political Research (ECPR), which in fact has been conducting a specific event for the discussion of gender, the European Conference on Politics and Gender, whose 5th edition was held in June 2017 in Lausanne, Switzerland. Gretchen Ritter and Nicole Mellow (2000) point out that gender studies have varied levels of reception in the different areas of PS in the United States. By dividing the area into four subfields (Political Theory, American Politics, Comparative Politics, and International Politics), these authors found large differences in the types and quantities of papers produced in each subfield, identifying that only in Political Theory were gender studies fully accepted. More recently, however, authors such as Amy Mazur (2016) observed that the debate has been established gradually in other subfields, as is the case of Comparative Public Policy. 


\section{Gender studies and the participation of women in Science: Brazil's panorama}

A recently published article in the newspaper Folha de São Paulo brought the impacting news that "women already produce half of the Science in Brazil" (BATISTA; RIGHETTI, 2017). The article presented the data that $49 \%$ of the scientific papers produced in the country are authored by women, as pointed out by Elsevier in the report Gender in the Global Research Landscape (ELSEVIER, 2017).

Despite this positive news, the studies produced in the country related to gender and science were not optimistic until quite recently. Lopes (1998), for example, stressed that the problem was started by negligence on the part of the social scientists and historians of science on the issue of women/gender in science. In the same year, Velho and León (1998) diagnosed the situation of women in Brazilian science as precarious based on a field survey with professors from Unicamp: "Women are still a minority despite a certain level of growth since the 1970s. They focus on some areas of knowledge, particularly those of lesser status, while having a very weak presence in others. They move very slowly in an academic career and rarely reach its top" (VELHO; LEÓN, 1998, p. 343).

In this context, a series of other studies were produced to examine the phenomenon. In theoretical terms, Eleonora Oliveira (2008) analyzed how gender can bring new contributions to the different areas of science. According to her, gender studies can expand the categories of analysis in social sciences and health, including issues such as daily routine, experience, and emotion. She also proposed to consider gender as a relational category (of attitude, behavior, and generally involving subjective aspects such as identity and sexuality).

A variety of empirical studies on the topic were also produced. Leta (2003) studied the representation of women in administrative positions at USP, in undergraduate courses at UFRJ, and as coordinators of research groups registered with CNPq, identifying that in addition to being underrepresented as teachers and students, they also received fewer scholarships for productivity. Jacqueline Leta and Grant Lewison (2003), in turn, have examined the scientific production of Brazilian women between 1997 and 2001 in the areas of astronomy, immunology, and oceanography. The conclusion was that, despite publishing similar numbers of papers with similar potential impact and with the same probability to participate in international collaborations, men still receive more research grants, suggesting the continuance of discrimination of gender in the fields evaluated.

More recently, Márcia Grossi et al. (2016) evaluated the overall picture of women in Science in Brazil between 2000 and 2013. They identified a steady growth in the number of women who complete their doctorate degree and noticed that they are particularly focused in three areas: Biological Sciences, Health Sciences, and Humanities. Despite the advances, the authors observed that women still face enormous obstacles in the country to be inserted and progress in their scientific careers.

\section{Research Method}

A bibliometric analysis was conducted with the objective of verifying the level of participation of women in Brazilian scientific production in the areas of Political Science and International Relations in the period from 2006 to 2016 . Some indicators were considered for the operationalization of the analysis. First, the 37 graduate programs categorized by CAPES in the areas of Political Science and International Relations were investigated, as listed on the Sucupira Platform ${ }^{2}$ on March 14, 2017. The objective in this first phase of the research was to explore three indicators, namely:

- Women's participation in the production of master's dissertations between the years 2006 and 2016;

- Women's participation in the production of doctoral theses between the years 2006 and 2016;

- The current representation of women on the faculty or as coordinators of these programs.

To collect data in this first phase, there was the need to circumvent the problem of a lack of information recorded on the material produced (theses and dissertations) in all the programs. Because of this, the strategy adopted was to search for such data by analyzing the Lattes curricula ${ }^{3}$ of all the teachers enrolled in such programs in order to observe the theses and dissertations completed under their supervision. There were 563 teachers analyzed in total. At this stage, advising in other programs outside the areas investigated were disregarded. The data were organized by dividing these advisors by sex (of teachers and students) and per year, building a broad database. When it was difficult to identify the sex of the advisee, their Lattes curriculum was analyzed. When the doubt

\footnotetext{
${ }^{2}$ Sucipira Platform is an online tool created in 2014 by the Brazilian government to collect information, perform analyzes and evaluations and be a reference base of the National Graduate System.

${ }^{3}$ The Lattes Curriculum is a standard record of teaching activities and research in Brazil hosted on the Lattes platform that, in addition to the database of résumés, also brings together research groups and institutions into a single system. For more information, visit http://lattes.cnpq.br/.
} 
persisted, they were counted as male in order not to interfere in a positive way in the participation of women. We had no difficulty in identifying the sex of faculty members. This same database provided support to assess the representativeness of women as teachers and coordinators of these programs.

For the second phase of the research, a list was created of the scientific production of women in documents published in the 15 journals categorized by CAPES as A1 and A2 (ranked in the quadrennium 2013-2016). The criteria for ranking journals in these categories are as follows. A1 are journals with at least $30 \%$ of articles with international collaboration or authored by researchers with institutional affiliation primarily from abroad. Other criteria to classify A1 journals are: 1) indexed in the SCImago/Scopus database with Editorial line and thematic vocation, as well as frequency of publications in the journal, reported on the Sucupira Platform; 2) Editorial Board formed by international authors of reference; 3) SJR indicators that allow measuring citations; 4) The position of the journal in the SJR index, (a) in the set of scientific publications, in (b) international publications of Political Science and International Relations and, in (c) publications of PS \& IR in Latin America; 5) Doubleblind peer review system; 6) Publish at least $85 \%$ of articles from authors who are not linked to the institution that is the journal's editor. A2 are journals with at least $15 \%$ of articles with international collaboration or authored by researchers with institutional affiliation primarily from abroad. Other criteria to classify A2 journals are: 1) Journals indexed in the SCImago/Scopus database; 2) Exclusive publication of original articles; 3) SJR indicator that allows measuring citations; 4) Published by a research institution, stricto sensu graduate school, national or international scientific society; 5) Double-blind peer review system; 6) Minimum publishing of at least twice a year; 7) Publish at least $85 \%$ of articles from authors who are not linked to the institution that is the journal's editor (André SANTOS, Rafael VILLA and André BEIRÃO, 2016: 3).

The documents considered were those that had at least one woman as author, regardless of the order of authorship. The indicators considered were:

- Women's participation in the production of scientific articles, considering the various possible types: articles, reviews, interviews, letters, among others, between the years 2006 and 2016;

- Frequency of women in the authorship of the articles most cited produced between the years 2006 and 2016 ;

- Participation of women as editor-in-chief and/or present on the editorial board of these journals.

In order to collect and analyze this data, all the issues published within the time period investigated were consulted and cataloged. Next, the following actions were taken to observe the existence of women among the most cited authors in the 15 scientific journals investigated. The website of the CAPES journals was consulted 4 in the field "Search by database" selecting the option "SciELO Citation Index (Web of Science)"5. Then in the field of basic research the name of the journal under investigation was entered, selecting the search index as "publication name". Furthermore, in the field "time period", the years 2006 to 2016 were selected, and each journal was evaluated in this way. On the page of results, the articles were classified as "Number of citations - highest to lowest," being cataloged the 3 most cited articles from each journal, checking for the existence of female authors. The results were tabulated in MS Excel and can be seen in Table 1.

The names present in the editorial board of these journals were investigated as well as the female presence as Editor-in-Chief. The only editors-in-chief considered were those thus indicated, and members indicated as "associate editors" were classified as belonging to the editorial and scientific board. The editorial and scientific board had different names in these journals, such as editorial council, editorial committee, scientific council, editorial consultants, etc. The searches were carried out between the days of August 16, 17, and 18, 2017 on the websites of the journals.

\section{Research Results}

\subsection{Participation of women in the production of master's dissertations}

In absolute terms, of the total of 2,338 master's dissertations cataloged between 2006 and $2016,1,247$ (53.3\%) were written by men and 1,091 (46.7\%) by women. Within the period investigated, in terms of dissertations produced in the areas of Political Science and International Relations, there was a certain balance when comparing the production of women with that of men. There were in fact signs of improvement in recent times. If in 2006 the total number of dissertations produced by women (67) was very similar to the total produced by men (77), currently these levels are converging and in the years 2014 and 2016, they were surpassed, reporting respectively 154 and 153

${ }^{4}$ This consultation was carried out on June 19, 2017.

${ }^{5}$ We found that if we had done the research using the database "Web of Science - Main Collection (Thomson Reuters Scientific)" the number of citations would be greater since this database is broader than Scielo. However, we chose to use Scielo because all 15 journals investigated are indexed in this database, but not all are indexed in Thomson Reuters Scientific. 
dissertations written by women, and 132 and 144 written by men. Thus, it is important to highlight the gender parity in the production of master's dissertations as a noteworthy achievement.

Graph 1 - Dissertations written by men and women, 2006-2016.

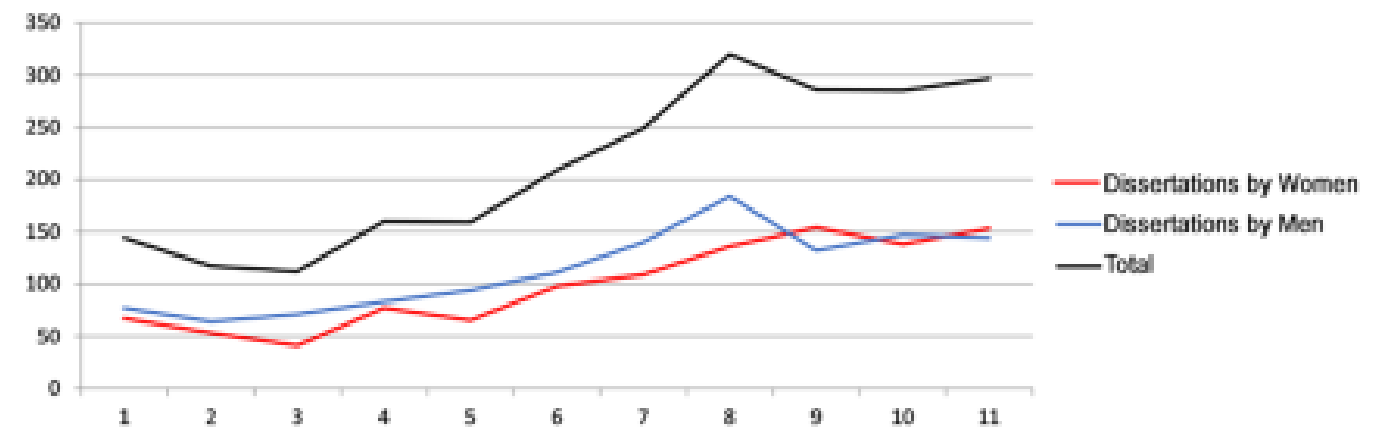

Source: Authors

However, differences are more evident when the focus is directed to faculty advisors. As for the advisors, for $1,625(69.5 \%)$ of these works they were men, and only for $713(30.5 \%)$ were they women. In 2006, 27.1\% of master's dissertations in PS and IR had a woman advisor, while in 2016 this percentage evolved to $35.7 \%$, which is the highest in the period considered. Of course, these data should be compared with the total number of men and women teachers in the period for a more detailed analysis of the situation.

Graph 2 - Dissertations with men and women advisors, 2006-2016.

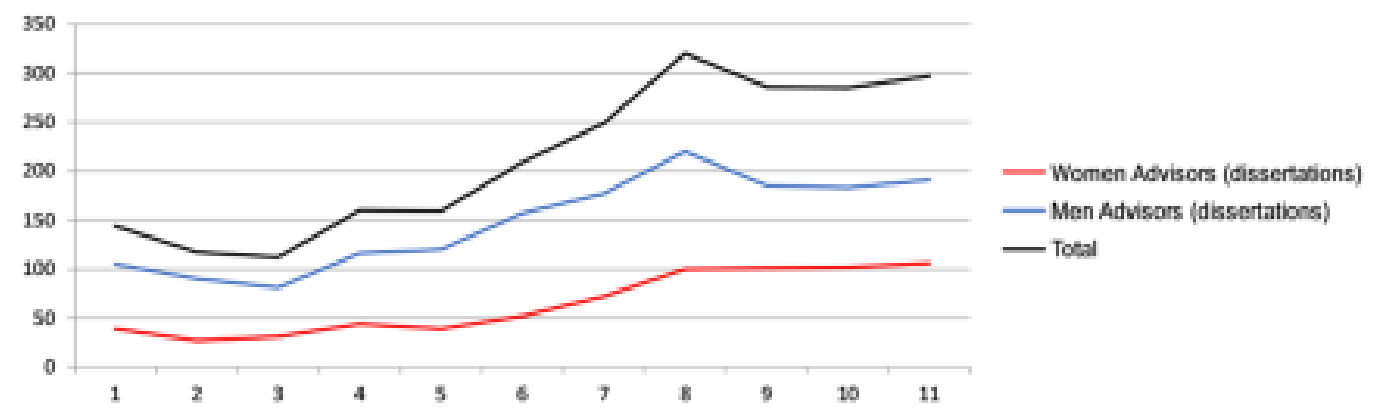

Source: Authors

\subsection{Participation of women in the production of doctoral theses}

When we consider the production of doctoral theses, the numbers show a lower female participation relatively to the master's dissertations. They wrote fewer doctoral theses than men in all years considered. The years in which there was a greater approximation were 2007 with 13 theses written by women and 20 by men, and 2011 in which 40 theses were written by women and 48 by men. However, it is worth noting that between 2006 and 2016, the number of theses defended by women grew $600 \%$ (from 6 to 42 ) while the growth in the number of theses written by men was $205.3 \%$ (from 19 to 58 ).

Graph 3 - Theses written by men and women, 2006-2016.

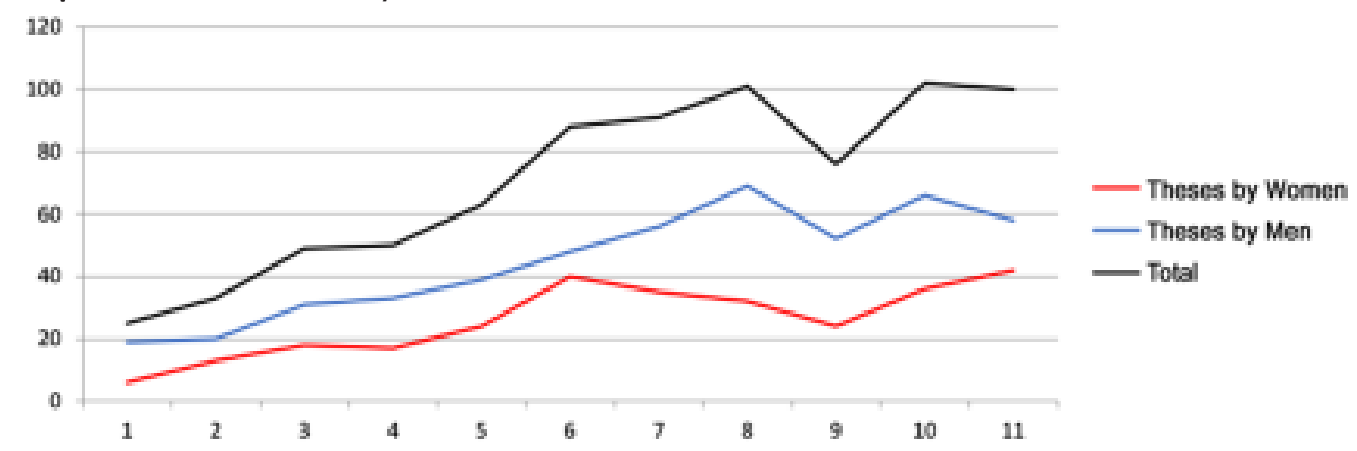

Source: Authors 
The numbers show more discrepancies when we focus on the sex of the advisors. In addition to there being fewer women than men as thesis advisors in all years considered, there was only a small percentage variation in female participation as advisors of this type (24\% in 2006 to $28 \%$ in 2016). Again, it should be noted that such data should be compared with the percentage of men and women on the faculty of the graduate programs analyzed.

Graph 4 - Theses with men and women advisors, 2006-2016.

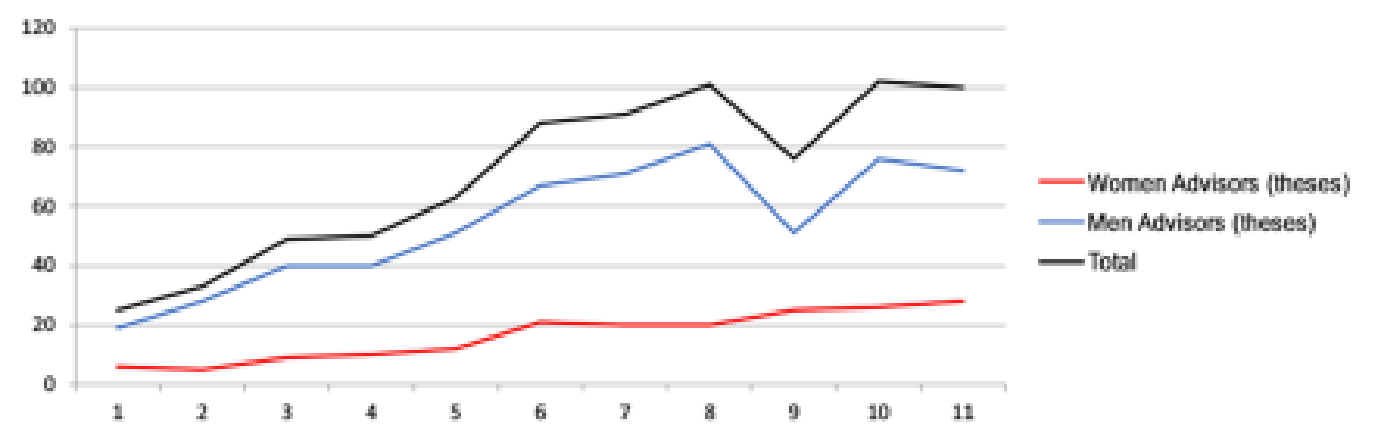

Source: Authors

In all there were 778 doctoral theses defended in the period, of which 491 (63.1\%) were authored by men and 287 (36.9\%) were authored by women. In other words, the divergence is greater than in relation to master's dissertations in disfavor of women. In addition, $596(76.6 \%)$ theses had men advisors and $182(23.4 \%)$ had women.

\subsection{Representation of women as faculty and coordinator}

The 37 graduate programs in all Brazil categorized by CAPES in the areas of Political Science and International Relations were considered. Of this total, 32 belonged to the academic modality and 5 to the professional modality ${ }^{6}$. Of the programs in the academic modality, 20 had master's and doctoral degrees and 12 had only a master's degree.

In absolute terms, these 37 programs brought together a total of 592 teachers of which 207 were women (35\%) and 385 were men $(65 \%)$. In addition, only 4 of these programs had more women than men among their teachers, and 2 of them had equal amounts. In other words, the overwhelming majority ( 31 or $83.7 \%$ ) has more men than women on its faculty. The results can be summarized as follows:

- Women represented more than $50 \%$ of the faculty: Social Cartography and Policies in the Amazon (UEMA), Public Policies (UEM), Analysis and Management of International Policies (PUC-Rio), Public Policies (UFRGS);

- Women represented exactly 50\% of the faculty: Public Policies and Human Rights (UFRJ) and International Relations (UERJ);

- Women represented between $50 \%$ and $30 \%$ of the faculty: Political Science (UFPEL), International Relations (UnB), International Relations (UFPB), International Relations (USP), International Relations (PUC-Rio), International Relations (UFSC), International Relations (PUC-MG), International Relations (UFU), Political Science (UFMG), Political Science (UFG), Political Science (UFSCar), Political Science (Unicamp), Political Science (UERJ), Political Science (UFRGS), Political Science (UFPA), Public Policies (UNIPAMPA);

-Women represented less than $30 \%$ of the faculty: Public Policies (UFABC), Public Policies (UFPE), Management of Public Policies and Social Security (UFRB), International Political Economy (UFRJ), Strategic International Studies (UFRGS), Political Science (UnB), Political Science (UFCG), Political Science (UFPE), Political Science (USP), Political Science (UFF), Political Science (UFPI), Political Science (UFPR), International Relations (San Tiago Dantas), International Relations (UFBA), Political Science and International Relations (UFPB).

In relation to the management of these programs, 11 of them were coordinated by women (29.7\%) and 26 were coordinated by men (70.3\%), which reveals that the positions of leadership are still essentially masculine.

\subsection{Participation of women in the production of scientific articles}

Our analysis showed that women participated in the production of $50.8 \%$ of the articles published in the 15 journals considered between 2006 and 2016. However, there was a high

${ }^{6}$ CAPES distinguishes Brazilian graduate programs as academic (with focus on research) and as professional (with focus on professional application of knowledge). 
variability in the participation of women among these journals. For example, journals such as Saúde e Sociedade and Cadernos de Pesquisa (Carlos Chagas Foundation) had high percentages of women among its authors ( $85.2 \%$ and $72.6 \%$, respectively) as contrasted with journals such as Revista de Economia Política and Novos Estudos CEBRAP, which had the lowest participation of women in the period $(23.7 \%$ and $28.7 \%$, respectively). Moreover, it is important to emphasize the higher female presence in journals focused on Health and Education in comparison with journals with other thematic foci.

Table 1- Participation of women (W) in the production of articles published between 2006 and 2016.

\begin{tabular}{|c|c|c|c|c|}
\hline Journal & Rank & W & Total & $\mathrm{W}(\%)$ \\
\hline Saúde e Sociedade (Online) & $\mathrm{A} 2$ & 869 & 1,02 & $85.2 \%$ \\
\hline Cademos de Pesquisa (Carlos Chagas Foundation. Printed) & $A 2$ & 377 & 519 & $72.6 \%$ \\
\hline Histária, Ciêncies, Saúde-Manguiunhos (Printed) & A2 & 621 & 1,068 & $58.1 \%$ \\
\hline Revista de Ad́ministraçâo Pública (Printed) & A2 & 371 & 672 & $55.2 \%$ \\
\hline Opiniâo Públice (UNICAMP. Printed) & A1 & 104 & 215 & $48.4 \%$ \\
\hline Cademo CRH (UFBA. Printed) & $A 2$ & 235 & 501 & $46.9 \%$ \\
\hline Dados (Rio de Janeiro. Printed) & $\mathrm{A} 1$ & 133 & 327 & $40,7 \%$ \\
\hline Contexto Internacional (on-line) & $A 2$ & 87 & 228 & $38.2 \%$ \\
\hline Revista Brasieira de Poñitica Intemacional (Online) & $\mathrm{A} 1$ & 100 & 273 & $36,6 \%$ \\
\hline Brazilian Political Science Review & $A 2$ & 70 & 191 & $36,6 \%$ \\
\hline Lue Nova (Printed) & A2 & 101 & 281 & $35.9 \%$ \\
\hline Revisfa Brasieira de Cièncias Sociais (Online) & $\mathrm{A} 1$ & 174 & 501 & $34.7 \%$ \\
\hline Revista de Sociologia e Politica (Online) & A2 & 143 & 427 & $33.5 \%$ \\
\hline Nowos Estudos CEBRAP (Online) & $A 2$ & 128 & 446 & $28.7 \%$ \\
\hline Revisfa de Economia Politica (Onine) & $\mathrm{A} 2$ & 112 & 472 & $23.7 \%$ \\
\hline Totals & & 3,625 & 7,141 & $50.8 \%$ \\
\hline
\end{tabular}

Source: Authors

On the other hand, the longitudinal analysis (year to year) did not show much percentage variability among the articles written by women in relation to the total number of articles published by the 15 journals. The lowest percentage was observed in 2006, when 220 articles written by women were published from a total of 503 articles ( $43.7 \%$ of female authorship), and the highest percentage occurred in 2013 with 386 articles with women authors out of the 691 articles in total (55.9\% of female authorship). We highlight that this indicator measures the participation of women as one of the authors, regardless of the order of authorship and of the presence of male authors in the same paper. While this does not invalidate the measure, it certainly restricts its meaning.

\subsection{Frequency of women authorship of most clted articles}

In the analysis of this indicator, we considered the three articles most often cited among all those published between 2006 and 2016 in the 15 journals analyzed. We examined how many of these articles had the participation of women as at least one of the authors. Of the total of 15 journals, 8 had exactly 1 article with a woman author among the three most cited (Group A), 5 journals had exactly 2 articles in this same situation (Group B), and in two of these journals (Group C) all three most cited articles had the participation of at least one female author.

- Group A: Opinião Pública (UNICAMP. Printed), Novos Estudos CEBRAP (Online), Revista de Economia Política (Online), Saúde e Sociedade (Online), Brazilian Political Science Review, Revista de Administração Pública (Printed), Dados (Rio de Janeiro. Printed), Revista Brasileira de Política Internacional (Online);

- Group B: Revista Brasileira de Ciências Sociais (Online), Caderno CRH (UFBA. Printed), Revista de Sociologia e Política (Online), Contexto Internacional (Online), História, Ciências, SaúdeManguinhos (Printed);

Group C: Cadernos de Pesquisa (Carlos Chagas Foundation. Printed), Lua Nova (Printed).

Furthermore, of the 45 articles considered ( 15 journals $x 3$ articles per journal), 24 had at least one female author (53.3\%) and 21 had only male authors (46.7\%). Even though we recognize that this indicator has its limitations (as pointed out above), it is a valid measure to observe the high relevance and impact of the female scientific production.

When we analyzed the average citations of articles with a female author $\left(\mu_{\text {female }}=18.83\right.$ citations per article), the result is very similar to the average number of citations of articles without the participation of women $\left(\mu_{\text {male }} 19.57\right.$ citations per article). Thus, these data reveal a high relevance of the scientific production of women in these journals, identified as those of higher quality in the areas of PS and IR. 


\subsection{Participation of women as Editors-in-Chief and on the Editorial and Sclentific Board of the journals.}

The participation of women as Editors-in-Chief and on the editorial and scientific boards of the journals evaluated was an indicator that showed a high disproportion between men and women. Seven journals (Opinião Pública, Brazilian Political Science Review, Caderno CRH, Contexto Internacional, Novos Estudos CEBRAP, Revista de Administração Pública and Saúde e Sociedade) had women as Editor-in-Chief. However, one of these jounals had 2 women in this position (Saúde e Sociedade). The remainder 8 journals had men as Editor-in-Chief, but one of them had 2 men in this position (História, Ciências, Saúde-Manguinhos) and other had 4 men in the post (Revista de Sociologia e Política). Thus, there were 13 men as Editor-in-Chief, while there were 8 women in the same position, considering all 15 journals.

Regarding the proportion of men and women on the Editorial and Scientific Boards of these journals, the totals are: Dados (25 men, 4 women), Opinião Pública ( 11 men, 6 women), Revista Brasileira de Ciências Sociais (19 men, 11 women), Revista Brasileira de Política Internacional (18 men, 9 women), Brazilian Political Science Review (34 men, 11 women), Caderno CRH (14 men, 11 women), Cadernos de Pesquisa (14 men, 21 women), Contexto Internacional (47 men, 11 women), História, Ciências, Saúde-Manguinhos (18 men, 22 women), Lua Nova (27 men, 4 women), Novos Estudos CEBRAP (21 men, 7 women), Revista de Administração Pública (1 7 men, 7 women), Revista de Economia Política (29 men, 3 women), Revista de Sociologia e Política (30 men, 2 women), Saúde e Sociedade (17 men, 13 women). In other words, only two of these journals had a higher proportion of women than men in their editorial and scientific boards.

Therefore, men represented $61.9 \%$ (13) of the Editors-in-Chief while women totaled only $38.1 \%$ (8). The female underrepresentation became even more evident when their participation was considered on the editorial and scientific boards of these journals. In total there were $341 \mathrm{men}$, or $70.6 \%$, and 142 women, representing $29.4 \%$. It should be noted that the composition of these boards is carried out by invitations addressed specifically to each of the members. This states very clearly the gender bias in the member choice process of these journals.

\section{Final Considerations}

This paper aimed to bring a recent diagnosis on the participation of women in scientific teaching and research within the areas of Political Science and International Relations in Brazil. To do so, we followed some research criteria to measure this participation within a period of 10 years (2006 to 2016). The data analysis was supported by a theoretical debate that has increasingly permeated various areas of Science, highlighting the role of women in many spheres of society, their rights, the victories already won, and the challenges still ahead.

Some Brazilian studies have sought to give a focus to the issue of gender within different areas of knowledge, but there were no analyses directed to the areas of Political Science and International Relations that had the same approach as this paper.

In this sense, the data presented in this study revealed that there is, in many of the indicators assessed, an upward trend in the participation of women within these areas of knowledge. However, there are also some exceptions. In the master's dissertations produced, there has been in recent times a certain gender balance that did not happen in the case of doctoral theses (highest degree in academia) where male predominance is quite evident. Another distortion of representativeness between sexes was found in the advisors for master's and doctoral degrees, which in spite of there being similar levels of academic degrees among the teachers, men have a predominance in strategic posts or functions within the organizations, such as advisors and also as coordinators of graduate programs.

The same picture could also be seen in strategic functions held in scientific journals such as Editor-in-Chief and on the Editorial and Scientific Board. In both cases there was a significant male predominance in these positions. The explanation for filling these strategic positions by men in the journals is not, however, linked to their importance in the national scientific production in these areas, because as noted, women already express a majority in this indicator. For example, women showed to have a majority in the participation in scientific publications of the journals investigated (of high impact) along with a high representation (53.3\%) in the authorship of most cited articles in relation to those papers with only male authorship (46.7\%). This shows that women have a considerably high production in scientific journals classified as A1 and A2 in the Qualis Capes. It is worth noting, however, that due to the "blind" evaluation of the peer reviewers of these journals, there is no way for them to know if the author of the article is a man or a woman, which favors the extraction of the weight of the variable "sex" in the judgment and in the decision made about the publication.

Finally, some future possibilities should be pointed out for studies that may aim to complement this diagnosis, for example, expanding the time frame or the number of indicators of analysis, or even building a portrait of other areas of knowledge. Surveys directed to understanding the 
phenomenon through perception analysis, comparative studies within the same areas of knowledge with other countries, or with other areas of knowledge, or even qualitative studies aiming to bring a more detailed observation of the phenomenon would complement the results of this paper and would enable a more holistic interpretation of the phenomenon investigated.

\section{References}

BATISTA, Everton; RIGHETTI, Sabine. "Mulheres já produzem metade da ciência do Brasil, diz levantamento". Folha de S. Paulo, March 8, 2017. Available at http://www1 .folha.uol.com.br/ sobretudo/carreiras/2017/03/1 864542-mulheres-ja-produzem-metade-da-ciencia-do-brasil-dizlevantamento.shtml. Accessed June 17, 2017.

CECI, Stephen; WILLIAMS, Wendy; BARNET, Susan. "Women's underrepresentation in science: sociocultural and biological considerations". Psychological Bulletin, v. 135, n. 2, 2009, p. 218-61.

COLGAN, Jeff. "Gender Bias in International Relations Graduate Education? New Evidence from Syllabi”. PS: Political Science \& Politics, v. 50, n. 2, 2017, p. 456-60.

DAHLERUP, Drude. "The development of gender and politics as a new research field within the framework of ECPR". European Political Science, v. 9, 2010, p. 85-98.

ELSEVIER. Gender in the Global Research Landscape. 2017. Available at https://www.elsevier.com/ data/assets/pdf file/0008/265661/ElsevierGenderReport_final_for-web.pdf. Accessed June 21, 2017.

GROSSI, Márcia; BORJA, Shirley; LOPES, Aline; ANDALÉCIO, Aleixina. "As mulheres praticando ciência no Brasil". Revista Estudos Feministas, v. 24, n. 1, 2016, p. 11-30.

HANSEN, Marie. "What is protest? Feminism, psychoanalysis and methods of social change". Gender and Education, v. 28, n. 3, 2016, p. 484-9.

HARAWAY, Donna. "A cyborg manifesto: science, technology, and socialist-feminism in the late twentieth century". In: Simians, Cyborgs, and Women: The Reinvention of Nature (pp. 149-82). New York: Routledge, 1991.

HENLEY, Megan. "Women's Success in Academic Science: challenges to breaking through the ivory ceiling". Sociology Compass, v. 9, n. 8, 2015, p. 668-80.

HILL, Catherine; CORBET, Christianne; ROSE, Andresse. "Why so few? Women in science, technology, engineering and mathematics". The American Association of University Women (AAUW), Washington, D.C., 2010.

KOSHLAND Jr, Daniel. “Women in science”. Science, v. 260, n. 5106, p. 275, 1993.

LEONE, Eugenia; TEIXEIRA, Marilane. "As mulheres no mercado de trabalho e na organização sindical". In: ENCONTRO NACIONAL DE ESTUDOS POPULACIONAIS, XVII, 2010, Caxambu/MG, Anais... Caxambu/MG: Associação Brasileira de Estudos Populacionais, 2010, p. 1-21. Available at http:// www.abep.nepo.unicamp.br/encontro2010/docs_pdf/tema_8/abep2010_2200.pdf. Accessed June $17,2017$.

LETA, Jacqueline. "As mulheres na ciência brasileira: crescimento, contrastes e um perfil de sucesso". Estudos Avançados, v. 17, n. 49, 2003, p. 271-84.

LETA, Jacqueline; LEWISON, Grant. "The contribution of women in Brazilian science: a case study in astronomy, immunology and oceanography". Scientometrics, v. 57, n. 3, 2003, p. 339-53.

LOPES, Maria. “'Aventureiras' nas ciências: refletindo sobre gênero e história das ciências naturais no Brasil". Cadernos Pagu, v. 10, 1998, p. 345-68.

MAZUR, Amy. "Mainstreaming Gender in Political Science Courses: the case of Comparative Public Policy". PS: Political Science \& Politics, v. 49, n. 3, 2016, p. 562-5.

MENDES, Marina. Gênero e Relações Internacionais: a inserção da mulher na esfera política e na carreira diplomática brasileira. 45p., 201 1. Monograph - XII Curso de Especialização em Relações Internacionais do Instituto de Relações Internacionais da Universidade de Brasília, Brasília, DF, Brasil. 
MERTUS, Julie. "Teaching gender in International Relations". International Studies Perspectives, v. 8, n. 3, 2007, p. 323-5.

MONTE, Izadora. "O debate e os debates: abordagens feministas para as relações internacionais". Revista Estudos Feministas, v. 21, n. 1, 2013, p. 59-80.

NARAIN, Seema. "Gender in International Relations: feminist perspectives of J. Ann Tickner". Indian Journal of Gender Studies, v. 21, n. 2, 2014, p. 179-97.

OLIVEIRA, Eleonora. "Gender, body and knowledge". Saúde e Sociedade, v. 17, n. 2, 2008, p. 7-10.

REITER, Dan. "The positivist study of gender in International Relations". Journal of Conflict Resolution, v. 59 , n. 7, 2015, p. 1301-26.

RITTER, Gretchen; MELLOW, Nicole. "The state of gender studies in Political Science". Annals of the American Academy of Political and Social Sciences, v. 571, 2000, p. 121-34.

ROSSI, Alice. "Women in science: why so few?" Science, v. 148, n. 3674, 1965, p. 1196-202.

SANTOS, André; VILLA, Rafael; BEIRÃO, André. Considerações sobre qualis periódicos: ciência política e relações internacionais. Coordenação de Aperfeiçoamento de Pessoal de Nível Superior - CAPES, Ministério da Educação, 2016. Available at http://www.capes.gov.br/images/documentos/ Qualis_periodicos_2016/Qualis_Ci\%C3\%AAncia_Pol\%C3\%ADtica.pdf. Accessed June 15, 2017.

SJOBERG, Laura. Gender and International Security. New York; London: Routledge, 2010.

STIENSTRA, Deborah. "Cutting to gender: teaching gender in International Relations". Pedagogy in International Studies, v. 1, n. 3, 2000, p. 233-44.

TICKNER, J Ann. Gender in International Relations: feminist perspectives on achieving global security. New York: Columbia University Press, 1992.

TICKNER, J Ann. Gendering World Politics: issues and approaches in the post-cold war era. New York: Columbia University Press, 2001.

URRY, Meg. "Scientists must work harder on equality". Nature, v. 528, n. 7583, 2015, p. 471-3.

VASCONCELLOS, Bruna; LIMA, Márcia. "Fanny Tabak e os primeiros passos dos estudos sobre ciência, tecnologia e gênero no Brasil”. Redes, v. 22, n. 43, 2016, p. 13-22.

VELHO, Léa; LEÓN, Elena. "A construção social da produção científica por mulheres". Cadernos Pagu, v. 10, 1998, p. 309-44.

Marcos Vinícius Isaias Mendes (mvinicius.imendes@gmail.com) é doutorando em Relações Internacionais na Universidade de Brasília (UnB). Mestre em Administração pela Universidade Federal do Rio de Janeiro (UFRJ), bacharel em Gestão de Comércio Internacional e bacharel em Administração, ambos pela Universidade Estadual de Campinas (Unicamp). Temas de pesquisa atuais: a) transição tecnológica, economia da informação, indústria 4.0, inteligência artificial e machine learning, e seus impactos na economia política internacional; b) empresas multinacionais de tecnologia da informação e sua atuação na governança global do clima. Membro do grupo de pesquisa "Sistema Internacional no Antropoceno e Mudança Global do Clima".

Ariane Cristine Roder Figueira (ariane.roder@coppead.ufrj.br) é docente do Instituto Coppead de Administração da Universidade Federal do Rio de Janeiro, coordenadora do Centro de Estudos de Cidades Inteligentes e pesquisadora sênior do Centro de Estudos em Negócios Internacionais e do Centro de Inovação e Sustentabilidade nessa mesma instituição. Doutora e mestre em Ciência Política pela USP e graduada em Ciências Sociais pela Unesp. Atua como pesquisadora e orienta trabalhos científicos nas áreas de negócios internacionais, internacionalização de empresas, política externa, gestão pública, sustentabilidade corporativa, instituições políticas e processo decisório. 


\section{COMO CITAR ESSE ARTIGO DE ACORDO COM AS NORMAS DA REVISTA}

MENDES, Marcos Vinícius Isaias; FIGUEIRA, Ariane Roder. "Women's Scientific Participation in Political Science and International Relations in Brazil". Revista Estudos Feministas, Florianópolis, v. 27, n. 2, e54033, 2019.

\section{CONTRIBUIÇÃO DE AUTORIA}

Marcos Vinícius Isaias Mendes - concepção, coleta de dados e análise de dados, elaboração do manuscrito, redação, discussão de resultados.

Ariane Roder Figueira - concepção, análise de dados, elaboração do manuscrito, discussão de resultados.

\section{FINANCIAMENTO}

O presente trabalho foi realizado com apoio da Coordenação de Aperfeiçoamento de Pessoal de Nível Superior - Brasil (CAPES) - Código de Financiamento 001.

CONSENTIMENTO DE USO DE IMAGEM

Não se aplica

APROVAÇÃO DE COMITÊ DE ÉTICA EM PESQUISA

Não se aplica

\section{CONFLITO DE INTERESSES}

Não se aplica

\section{LICENÇA DE USO}

Este artigo está licenciado sob a Licença Creative Commons CC-BY Internacional. Com essa licença você pode compartilhar, adaptar, criar para qualquer fim, desde que atribua a autoria da obra.

\section{HISTÓRICO}

Recebido em 15/1 1/2017

Reapresentado em 13/07/2018

Aprovado em 13/08/2018

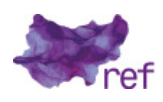

